\title{
Imaging Synaptic Inhibition with the Genetically Encoded Chloride Indicator Clomeleon
}

\author{
Ken Berglund, Thomas Kuner, Guoping Feng, and George J. Augustine
}

Several techniques are available to image excitatory processes in the brain, but synaptic inhibition has remained largely invisible. Most synaptic inhibition in the brain arises from transmembrane fluxes of chloride ions $\left(\mathrm{Cl}^{-}\right)$, so imaging intracellular $\mathrm{Cl}^{-}$concentration $\left(\left[\mathrm{Cl}^{-}\right]_{\mathrm{i}}\right)$ is, in principle, a natural way to visualize the spatiotemporal dynamics of inhibition. This protocol describes the use of Clomeleon, a genetically encoded indicator of $\mathrm{Cl}^{-}$, as a tool for monitoring synaptic inhibition. It outlines procedures that can be used to image neuronal $\left[\mathrm{Cl}^{-}\right]_{\mathrm{i}}$ in brain slices prepared from Clomeleon transgenic mice. With only minor adjustments, the same procedures should be suitable for imaging from cultured cells as well.

It is essential that you consult the appropriate Material Safety Data Sheets and your institution's Environmental Health and Safety Office for proper handling of equipment and hazardous materials used in this protocol.

Artificial cerebrospinal fluid (ACSF)

Chloride solution (see Step 8)

Clomeleon transgenic mice, 2-3-wk-old

Gluconate or $\mathrm{F}^{-}$(see Step 7)

Isoflurane

Nigericin

Tributyltin (an $\mathrm{OH}^{-} / \mathrm{Cl}^{-}$antiporter)

Equipment

Dissection tools

Imaging setup for epifluorescence or two-photon imaging

An upright epifluorescence microscope (e.g., Nikon's Eclipse E600FN or equivalent) equipped with a mercury lamp, a 515-nm dichroic mirror, a filter wheel, and excitation (440 $\pm 10 \mathrm{~nm})$ and emission filters (485 $\pm 15 \mathrm{~nm}$ for cyan fluorescent protein [CFP]; $530 \pm 15 \mathrm{~nm}$ for yellow fluorescent protein [YFP]) is used to image Clomeleon fluorescence. Fluorescence excitation is produced by 200-msec-long light pulses $(0.5 \mathrm{~Hz})$ and fluorescence emission is collected alternately at each wavelength with a cooled charge-coupled device (CCD) camera with on-chip multiplication gain control (Cascade 512B, Photometrics).

Adapted from Imaging in Neuroscience (ed. Helmchen and Konnerth). CSHL Press, Cold Spring Harbor, NY, USA, 2011.

(C) 2011 Cold Spring Harbor Laboratory Press

Cite this article as Cold Spring Harbor Protoc; 2011; doi:10.1101/pdb.prot066985 


\section{METHOD}

\section{Slice Preparation}

Clomeleon fluorescence also can be imaged with a two-photon microscope (Ultima IV, Prairie Technologies) using 860-nm laser light (Chameleon Ultra II, Coherent) and a $\times 40$ water-immersion objective (LUMPLFL40xW/IR/0.80, Olympus) with total output power $<50 \mathrm{~mW}$. In this case, a fluorescence filter cube with an emission beam splitter (71007, Chroma) is used for fluorescence emission.

Incubation chamber

Incubator preset to $37^{\circ} \mathrm{C}$

Vibratome

Hippocampal slices are prepared from transgenic mice using conventional methods (see, e.g., Berglund et al. 2006).

1. Anesthetize the mice with isoflurane.

2. Decapitate the animals. Immerse the skulls in chilled ACSF.

3. Working quickly, remove the brains. Keep the brains in chilled ACSF.

4. Using a vibratome, cut $250-\mu \mathrm{m}$-thick sagittal sections of the hippocampus. Transfer sections to an incubation chamber containing ACSF.

5. Incubate the slices for $30 \mathrm{~min}$ at $37^{\circ} \mathrm{C}$ before imaging with epifluorescence or two-photon imaging.

See the Discussion for an example of how the preparation can be used.

\section{Calibration Procedure}

The Clomeleon fluorescence emission ratio can be converted into $\left[\mathrm{Cr}_{\mathrm{i}}\right.$ (Berglund et al. 2009), as is described briefly here.

6. Incubate brain slices in situ at $\mathrm{pH} 7.1$ in the presence of tributyltin (Inglefield and SchwartzBloom 1997; Berglund et al. 2006).

Because $\mathrm{pH}$-dependent exchangers such as the $\mathrm{Cl}^{-} / \mathrm{HCO}_{3}^{-}$exchanger (Krapf et al. 1988) can change $\mathrm{Cl}^{-}$], the $\mathrm{K}^{+} / \mathrm{H}^{+}$ionophore nigericin is also added to clamp the intracellular $\mathrm{pH}$ to the value of the extracellular $\mathrm{pH}$. Under these conditions, tributyltin equilibrates $\left[\mathrm{Cl}^{-}\right]_{i}$ with $\left[\mathrm{Cl}^{-}\right]_{0}$.

7. Incubate the slices with solutions of $\mathrm{F}^{-}$or gluconate to determine the values when Clomeleon is $\mathrm{Cl}^{-}$-bound $\left(R_{\min }\right)$ or $\mathrm{Cl}^{-}$-free $\left(R_{\max }\right)$.

8. To calculate the effective $\mathrm{Cl}^{-}$dissociation constant of Clomeleon $\left(K_{\mathrm{d}}{ }^{\prime}\right)$, incubate slices with two known concentrations of $\mathrm{Cl}^{-}$(50 and $134 \mathrm{mM}$ ).

9. Calculate the $\left[\mathrm{Cl}^{-}\right]_{\mathrm{i}}$ using the equation $\left[\mathrm{Cl}^{-}\right]_{\mathrm{i}}=K_{\mathrm{d}}{ }^{\prime} \mathrm{x}\left[\left(R_{\max }-R\right) /\left(R-R_{\min }\right)\right]$.

\section{DISCUSSION}

\section{Background}

Clomeleon is a fusion protein consisting of CFP and YFP, joined by a flexible 24-amino acid linker (Fig. 1A; Kuner and Augustine 2000). Because of the close spatial proximity of the two fluorophores, fluorescence resonance energy transfer (FRET) occurs. Thus, exciting the CFP donor causes the YFP acceptor to be excited and to emit yellow fluorescence. Binding $\mathrm{Cl}^{-}$to YFP quenches the yellow fluorophore (Jayaraman et al. 2000) and decreases the degree of FRET. Thus, measuring the ratio of emission of YFP relative to that of CFP (while exciting CFP) provides an absolute measure of the internal $\mathrm{Cl}^{-}$concentration $\left(\left[\mathrm{Cl}^{-}\right]_{\mathrm{i}}\right)$. Imaging of the fluorescence lifetime of the CFP donor is another way to use Clomeleon to monitor changes in $\left[\mathrm{Cl}^{-}\right]_{\mathrm{i}}$ (Jose et al. 2007). 
K. Berglund et al.
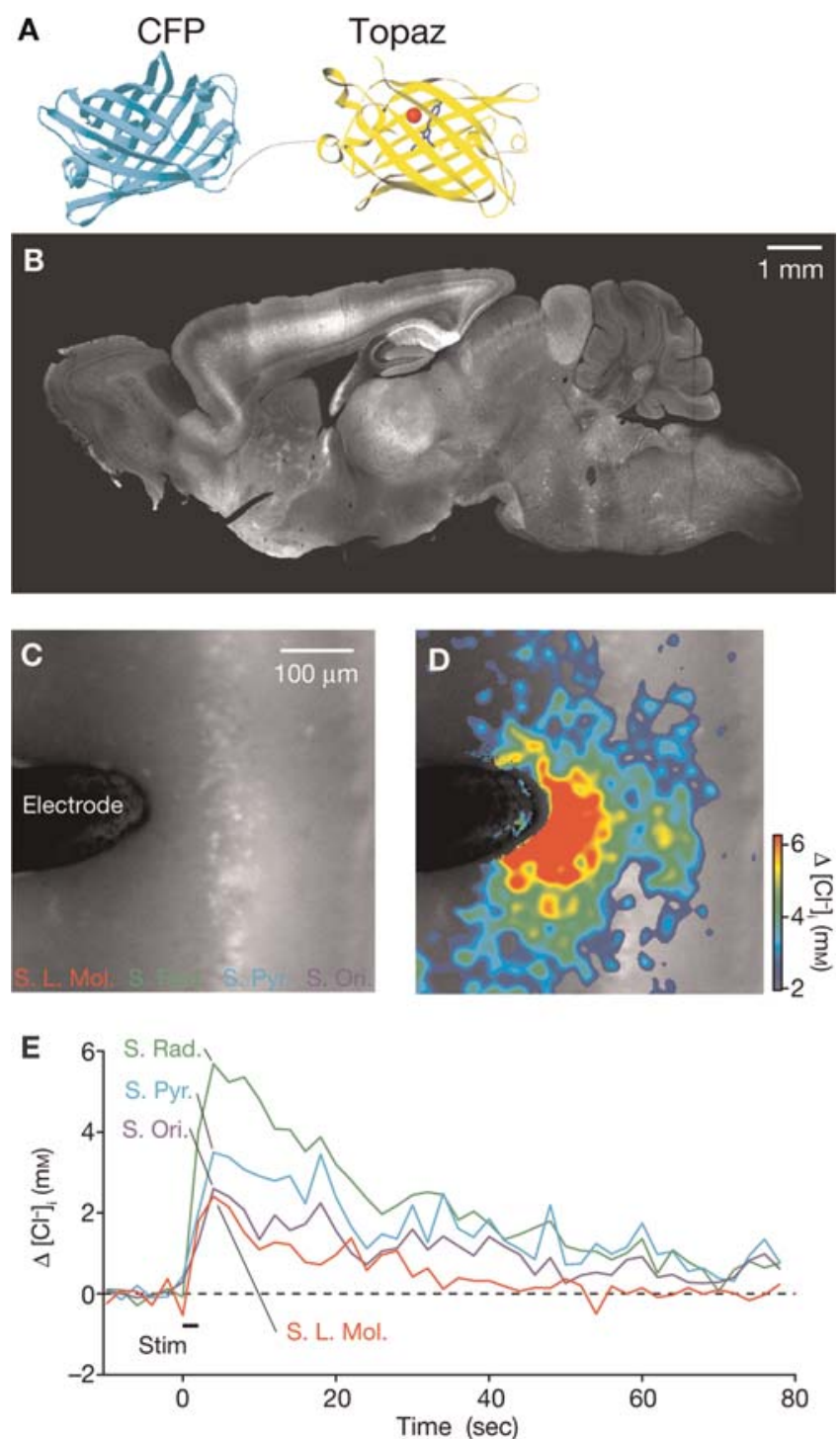

FIGURE 1. (A) Structure of Clomeleon. CFP (cyan) and Topaz (yellow) are connected by a short linker (gray). Shown inside Topaz are the halide-binding site (red) and the nearby chromophore (blue). (B) Expression of Clomeleon in the brain of an adult thy $1:$ Clomeleon mouse. The image shows YFP fluorescence in a paramedial sagittal section of fixed brain from a CLM11 mouse. (C) Image of YFP Clomeleon fluorescence (grayscale) expressed in CA1 pyramidal cells from a CLM1 hippocampal slice. (D) $\mathrm{Cl}^{-}$changes (pseudocolor scale) of the same areas shown in $(C)$ in response to a train of electrical stimuli delivered through the stimulating electrode (left side of image). The $\mathrm{Cl}^{-}$image was acquired 4 sec after the stimulus. S. L. Mol., stratum lacunosum moleculare; S. Rad., stratum radiatum; S. Pyr., stratum pyramidale; S. Ori., stratum oriens. $(E)$ Time course of changes in $[\mathrm{Cl}-]_{i}$ calculated from each layer. Duration of the 2-sec stimulus train (Stim) is indicated by a bar.

Clomeleon imaging has found a wide range of applications, both in vitro and in vivo (Berglund et al. 2008). Such applications are by no means limited to the brain; any cellular system that permits expression of exogenous DNAs or RNAs, or introduction of a recombinant protein that has been expressed in some other way, is appropriate for Clomeleon-based $\mathrm{Cl}^{-}$imaging (Lorenzen et al. 2004). The specific goals of the work described here are to document the ability to target Clomeleon expression to neurons in the mouse brain and to use Clomeleon to measure $\left[\mathrm{Cl}^{-}\right]_{\mathrm{i}}$ in these neurons.

The studies described here use lines of transgenic mice that express Clomeleon under the control of a neuron-specific promoter, thyl (Feng et al. 2000). The transgene has been used to produce several 
lines of transgenic mice, each of which expresses Clomeleon in specific subsets of neurons (Berglund et al. 2006). These mosaic patterns of expression are heritable and are therefore found in all individuals of a given line. One of the lines expresses Clomeleon within CA1 pyramidal cells in the hippocampus, as well as in neurons of many other brain regions (Fig. 1B). We are in the process of making these mice commercially available via the Jackson Laboratory (www.jax.org).

\section{Example of Application}

To determine whether chronically expressed Clomeleon could report $\left[\mathrm{Cl}^{-}\right]_{\mathrm{i}}$ changes associated with synaptic inhibition, changes in Clomeleon signals were measured in response to electrical stimulation $(800 \mu \mathrm{A}$ for $1 \mathrm{sec}$ at $20 \mathrm{~Hz}$ ) via a concentric bipolar metal electrode placed in the stratum lacunosum moleculare of hippocampal slices from transgenic mice. All measurements were made in the presence of $3 \mathrm{~mm}$ kynurenic acid (a glutamate antagonist) to prevent activation of excitatory synapses (Fig. 1C). A train of stimuli produced a transient increase in $\left[\mathrm{Cl}^{-}\right]_{\mathrm{i}}$ of $\sim 3 \mathrm{mM}$ (Fig. 1D), which returned to baseline within 30-50 sec (Fig. 1E). The $\mathrm{Cl}^{-}$transient was almost completely blocked by $10 \mu \mathrm{M}$ of the $\mathrm{GABA}_{\mathrm{A}}$ receptor antagonist gabazine, indicating that the transient was the result of activation of $\mathrm{GABA}_{\mathrm{A}}$ receptors. These results indicate that Clomeleon can report changes in neuronal $\left[\mathrm{Cl}^{-}\right]_{\mathrm{i}}$ associated with synaptic inhibition. By measuring $\left[\mathrm{Cl}^{-}\right]_{\text {i }}$ over many (e.g., $>20$ ) cells, Clomeleon can detect $\left[\mathrm{Cl}^{-}\right]_{\mathrm{i}}$ transients of $\sim 200 \mu \mathrm{M}$ caused by only five inhibitory postsynaptic potentials (Berglund et al. 2006). In addition, Clomeleon allows detection of gradients in $\left[\mathrm{Cl}^{-}\right]_{\mathrm{i}}$ associated with synaptic activity (Fig. 1E).

Not all FRET-based indicator proteins are suitable for two-photon microscopy. However, twophoton excitation spectra of cerebellar granule cells in slices prepared from Clomeleon transgenic mice (Fig. 2A) showed that emission of both CFP and YFP was brightest when excited by $860-\mathrm{nm}$ light (Fig. 2B). The YFP/CFP emission ratio was also relatively high at $860 \mathrm{~nm}$ (Fig. 2B). To determine
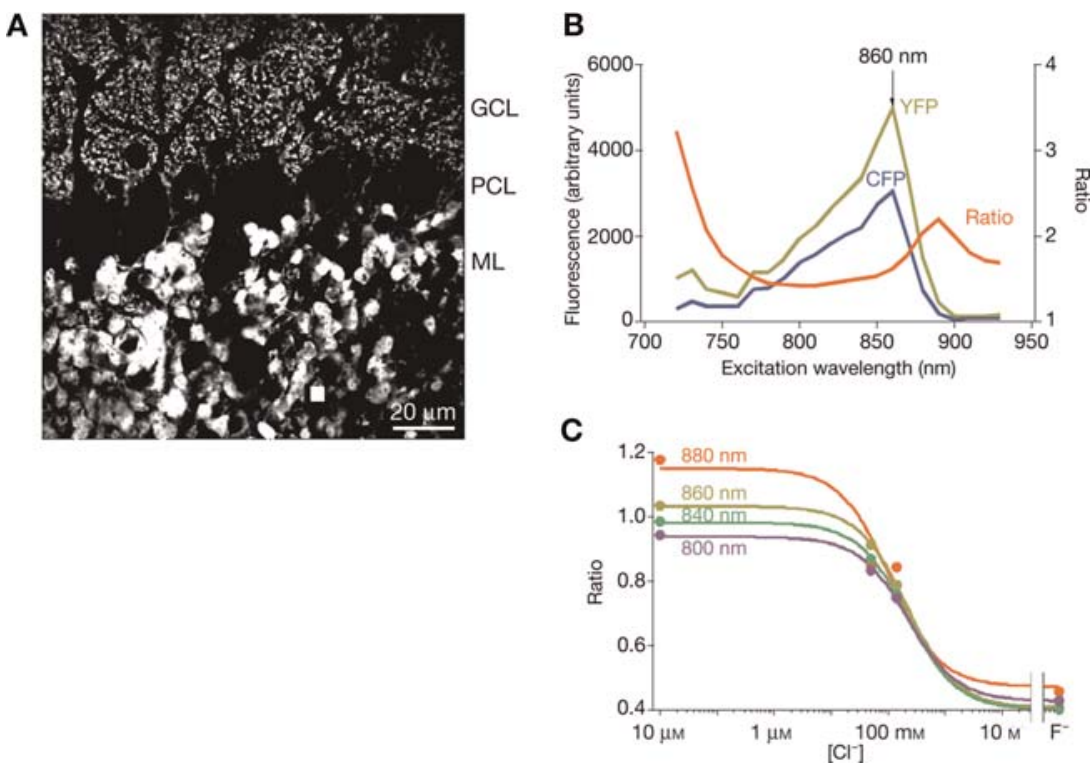

FIGURE 2. (A) A two-photon image of YFP fluorescence in the cerebellar cortex, showing expression of Clomeleon exclusively in granule cells. Both the molecular layer (ML) and granule cell layer (GCL) are fluorescent, indicating the presence of Clomeleon in granule cell bodies/dendrites and parallel fibers. Note that Purkinje cell bodies do not express Clomeleon, as indicated by the absence of YFP fluorescence in the Purkinje cell layer (PCL). (B) Twophoton excitation spectrum of Clomeleon. Both the CFP and YFP fluorescences of Clomeleon were brightest when excited by $860-\mathrm{nm}$ light. The YFP/CFP emission ratio (Ratio) was also relatively high at $860 \mathrm{~nm}$. (C) $\mathrm{Cl}^{-}$titration curves for Clomeleon measured at various excitation wavelengths. $\left[\mathrm{Cl}^{-}\right]_{i}$ was clamped at $[\mathrm{Cl}-]_{0}$ using a $\mathrm{Cl}^{-} / \mathrm{H}^{+}$antiporter/ionophore cocktail, as described in the text. Using an 860-nm excitation light, the dynamic range of Clomeleon was nearly maximal. 
K. Berglund et al.

the sensitivity of Clomeleon to $\mathrm{Cl}^{-}$, the Clomeleon emission ratio was measured at different excitation wavelengths and at different $\left[\mathrm{Cl}^{-}\right]$values (Fig. 2C). Half-maximal quenching of Clomeleon occurred

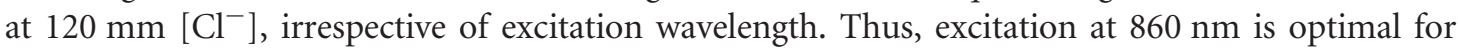
Clomeleon-based measurements of $\left[\mathrm{Cl}^{-}\right]_{\mathrm{i}}$. These results indicate that chronically expressed Clomeleon is suitable for two-photon imaging of $\left[\mathrm{Cl}^{-}\right]_{\mathrm{i}}$ (Duebel et al. 2006). This permits in vivo measurement of $\left[\mathrm{Cl}^{-}\right]_{\mathrm{i}}$ in the brains of Clomeleon transgenic mice (Berglund et al. 2009) and is being used to image tonic inhibition of granule cells by ambient GABA in vivo, as well as in slices in vitro (Lee et al. 2010).

\section{Advantages and Limitations}

Clomeleon offers two distinct advantages over existing $\mathrm{Cl}^{-}$indicator dyes. The first is that Clomeleon can be targeted to specific cells via genetic targeting. Using specific promoters, stereotaxic delivery of viruses, and/or Cre recombinase techniques, Clomeleon expression already has been targeted to a variety of neuronal types (Berglund et al. 2008), and it is very likely that such applications will expand in the future. Second, Clomeleon is ratiometric and, therefore, permits determination of absolute $\left[\mathrm{Cl}^{-}\right]$within the cells of interest. In addition, unlike other FRET-based indicator proteins, Clomeleon does not require a conformational change between the units of the FRET pair because quenching of YFP by $\mathrm{Cl}^{-}$is sufficient to induce a change in the YFP/CFP emission ratio. Thus, Clomeleon permits efficient two-photon excitation by Ti:sapphire lasers, enabling studies in visible lightsensitive retinas (Duebel et al. 2006) and in the mouse brain in vivo (Berglund et al. 2008).

There are three significant limitations when using Clomeleon to image $\left[\mathrm{Cl}^{-}\right]_{\mathrm{i}}$.

- Clomeleon is sensitive to protons, with lower $\mathrm{pH}$ increasing the affinity of Clomeleon for $\mathrm{Cl}^{-}$ (Kuner and Augustine 2000). In practice, interference by protons is minimal when $\left[\mathrm{Cl}^{-}\right]_{\mathrm{i}}$ is low, as is the case under most physiological conditions. In an experimental paradigm in which higher $\left[\mathrm{Cl}^{-}\right]_{\mathrm{i}}$ and/or significant $\mathrm{pH}$ changes are expected, the internal $\mathrm{pH}$ of the cells under investigation should be measured by conventional, organic $\mathrm{pH}$ indicator dyes so that the known relationship between $\mathrm{pH}$ and Clomeleon affinity (Kuner and Augustine 2000) can be used to calibrate Clomeleon responses accurately (Pond et al. 2006; Berglund et al. 2009).

- Intense illumination of Clomeleon causes differential bleaching of CFP and YFP, leading to a decrease in the Clomeleon emission ratio. This artifact can incorrectly indicate an increase in $\left[\mathrm{Cl}^{-}\right]_{\mathrm{i}}$. In practice, this problem can be avoided by minimizing the intensity and duration of Clomeleon excitation and by using highly sensitive CCD cameras or photomultiplier tubes.

- The affinity of Clomeleon for $\mathrm{Cl}^{-}$is not optimal, being $\sim 90 \mathrm{~mm}$ (Kuner and Augustine 2000), whereas $\left[\mathrm{Cl}^{-}\right]_{\mathrm{i}}$ in mature neurons is in the order of $5 \mathrm{~mm}$ (Berglund et al. 2006). This means that the sensitivity of Clomeleon for detecting synaptic inhibition is limited, particularly in neurons in which the membrane potential is not voltage clamped and the changes in $\left[\mathrm{Cl}^{-}\right]_{\mathrm{i}}$ associated with synaptic inhibition are $<<1 \mathrm{~mm}$ (Berglund et al. 2006). This limitation can be overcome by signal averaging over many cells and/or trials (Berglund et al. 2006), although the ultimate solution is to reengineer Clomeleon to improve its $\mathrm{Cl}^{-}$binding properties.

Despite these limitations, the utility of Clomeleon for measuring $\left[\mathrm{Cl}^{-}\right]_{\mathrm{i}}$ makes this indicator a valuable tool for analysis of the spatiotemporal dynamics of inhibitory networks in living brain tissue.

K.B. was a Research Fellow of the Japan Society for the Promotion of Science. This work was partially supported by Deutsche Forschungsgemeinschaft grant KU1983/1-2 (FOR 577) awarded to T.K., National Institutes of Health grants awarded to G.J.A. and G.F., and an Alfred P. Sloan Research Fellowship, a Klingenstein Fellowship Award in the Neurosciences, and a Beckman Young Investigator Award to G.F. 


\section{REFERENCES}

Berglund K, Schleich W, Krieger P, Loo LS, Wang D, Cant NB, Feng G, Augustine GJ, Kuner T. 2006. Imaging synaptic inhibition in transgenic mice expressing the chloride indicator, Clomeleon. Brain Cell Biol 35: 207-228.

Berglund K, Schleich W, Wang H, Feng G, Hall WC, Kuner T, Augustine GJ. 2008. Imaging synaptic inhibition throughout the brain via genetically targeted Clomeleon. Brain Cell Biol 36: 101-118.

Berglund K, Kuner T, Augustine GJ. 2009. Clomeleon, a genetically encoded chloride indicator. In Physiology and pathology of chloride transporters and channels in the nervous system (ed. Alvarez-Leefmans FJ, Delpire E), pp. 125-140. Academic, London.

Duebel J, Haverkamp S, Schleich W, Feng G, Augustine GJ, Kuner T, Euler T. 2006. Two-photon imaging reveals somatodendritic chloride gradient in retinal ON-type bipolar cells expressing the biosensor Clomeleon. Neuron 49: 81-94.

Feng G, Mellor RH, Bernstein M, Keller-Peck C, Nguyen QT, Wallace M, Nerbonne JM, Lichtman JW, Sanes JR. 2000. Imaging neuronal subsets in transgenic mice expressing multiple spectral variants of GFP. Neuron 28: 41-51.

Inglefield JR, Schwartz-Bloom RD. 1997. Confocal imaging of intracellular chloride in living brain slices: Measurement of $\mathrm{GABA}_{\mathrm{A}}$ receptor activity. J Neurosci Methods 75: 127-135.
Jayaraman S, Haggie P, Wachter RM, Remington SJ, Verkman AS. 2000. Mechanism and cellular applications of a green fluorescent proteinbased halide sensor. J Biol Chem 275: 6047-6050.

Jose M, Nair DK, Reissner C, Hartig R, Zuschratter W. 2007. Photophysics of Clomeleon by FLIM: Discriminating excited state reactions along neuronal development. Biophys J 92: 2237-2254.

Krapf R, Berry CA, Verkman AS. 1988. Estimation of intracellular chloride activity in isolated perfused rabbit proximal convoluted tubules using a fluorescent indicator. Biophys J 53: 955-962.

Kuner T, Augustine GJ. 2000. A genetically encoded ratiometric indicator for chloride: Capturing chloride transients in cultured hippocampal neurons. Neuron 27: 447-459.

Lee S, Yoon BE, Berglund K, Oh SJ, Park H, Shin HS, Augustine GJ, Lee CJ. 2010. Channel-mediated tonic GABA release from glia. Science 330: 790-796.

Lorenzen I, Aberle T, Plieth C. 2004. Salt stress-induced chloride flux: A study using transgenic Arabidopsis expressing a fluorescent anion probe. Plant J 38: 539-544.

Pond BB, Berglund K, Kuner T, Feng G, Augustine GJ, Schwartz-Bloom RD. 2006. The chloride transporter $\mathrm{Na}^{+}-\mathrm{K}^{+}-\mathrm{Cl}^{-}$cotransporter isoform-1 contributes to intracellular chloride increases after in vitro ischemia. J Neurosci 26: 1396-1406. 


\section{Imaging Synaptic Inhibition with the Genetically Encoded Chloride Indicator Clomeleon}

Ken Berglund, Thomas Kuner, Guoping Feng and George J. Augustine

Cold Spring Harb Protoc; doi: 10.1101/pdb.prot066985

\begin{tabular}{|c|c|}
\hline $\begin{array}{l}\text { Email Alerting } \\
\text { Service }\end{array}$ & Receive free email alerts when new articles cite this article - click here. \\
\hline $\begin{array}{l}\text { Subject } \\
\text { Categories }\end{array}$ & $\begin{array}{l}\text { Browse articles on similar topics from Cold Spring Harbor Protocols. } \\
\text { Calcium Imaging ( } 116 \text { articles) } \\
\text { Electrophysiology (104 articles) } \\
\text { Fluorescent Proteins ( } 259 \text { articles) } \\
\text { Imaging for Neuroscience ( } 342 \text { articles) } \\
\text { Mouse (437 articles) } \\
\text { Multi-Photon Microscopy (103 articles) } \\
\text { Transgenic Mice (139 articles) }\end{array}$ \\
\hline
\end{tabular}

